\title{
Relationship between obesity and asthma symptoms among children in Ahvaz, Iran: a cross sectional study
}

\author{
Tahereh Ziaei Kajbaf $^{1 *}$, Shideh Asar ${ }^{2 \dagger}$, Mohammad Reza Alipoor ${ }^{3+}$
}

\begin{abstract}
Background: Obesity has been identified as a risk factor for higher prevalence of asthma and asthma-related symptoms in children. The objective of this study was to evaluate the relationship between the prevalence of asthma symptoms and obesity among school-age children in the city of Ahvaz, Iran.

Methods: A total of 903 children, 7 to 11 years of age, were enrolled in this study through cluster sampling. The International Study of Asthma and Allergies in Childhood (ISAAC) questionnaire was used to identify the children who were currently suffering from asthma. Height and weight were measured and body mass index (BMI) was calculated in $\mathrm{kg} / \mathrm{m}^{2}$. Overweight was defined as BMl greater than the age- and sex-specific 85th percentile, and obesity as BMI greater than the 95th percentile. We determined the relationship between obesity and asthma symptoms by chi-square tests.

Results: The prevalence of wheeze ever, current wheezing, obesity, and overweight was $21.56 \%, 8.7 \%, 6.87 \%$, and $9.5 \%$, respectively. The current prevalence of wheezing among obese and overweight children was $68.75 \%$ and $37 \%$, respectively, and there was a statistical association between obesity and the prevalence of current wheezing ( $p<0.001$ ), night cough $(p<0.001)$, and exercise-induced wheezing $(p=0.009)$, but obesity and overweight were not associated with eczema and allergic rhinoconjunctivitis, so it seems that the pathophysiology of asthma in obese and overweight children is not related to allergy.
\end{abstract}

Conclusion: There is a strong association between asthma symptoms and both overweight and obesity in both sexes among school-age children.

\section{Introduction}

Asthma is characterized by episodic airflow obstruction, increased airway responsiveness, and airway inflammation. Asthma is a growing threat to the health of children [1]. The prevalence of asthma among school-age children has been rising in many regions of the developed world [2-6]. Also, in the past 2 decades there has been a significant increase in the prevalence of obesity among children worldwide [7].

It has been recognized that obesity is more common among children with asthma, and associations between asthma and obesity have been observed in cross-

\footnotetext{
*Correspondence: ziaei42@yahoo.co.uk

+ Contributed equally

'Pediatric Department, Abuzar Children's Hospital, Ahvaz Jondishapour

University of Medical Sciences, (Golestan street), Ahvaz, Iran

Full list of author information is available at the end of the article
}

sectional studies of adults and children [8,9]. Prospective studies with healthy non-asthmatic participants showed that a gain in weight increased the risk of asthma in adults and adolescents $[10,11]$. Finally, some studies in asthmatic patients showed that weight loss resulted in an improvement in lung function, symptoms, and health status [12,13]. Nevertheless, the relationship between obesity and asthma remains controversial [14] as some studies could not disclose any significant correlation between asthma as defined by bronchial hyper-responsiveness and obesity, and explained that the reported association between asthma and obesity might be due to a misinterpretation of noisy breathing in overweight subjects $[15,16]$. The obesity is a potentially modifiable risk factor, in which its relationship to asthma incidence should be clarified [17]. 
This study was conducted to determine whether obesity, as measured by body mass index (BMI), was associated with a higher prevalence of asthma symptoms. Possible differences between boys and girls were also evaluated.

\section{Methods}

In the autumn of 2009, we studied a random sample of children in the city of Ahvaz, Iran. The sampling frame included primary schools that were randomly selected from different parts of Ahvaz to obtain the required number of children. All children aged 7 to 11 years at each selected school were invited to participate and were studied after their parents' informed consent was obtained. The International Study of Asthma and Allergies in Childhood (ISAAC) questionnaire [18] was used to identify the children currently suffering from asthma. Standard guidelines for translation of the questionnaire from English into the Persian was used [19]. The questionnaires were distributed to parents of 1000 children. The questionnaire included questions on demographic characteristics, wheeze ever, current history of wheezing, diagnosed asthma, exercise-induced wheezing, and nocturnal cough. The questionnaire was completed at the schools by the children's parents and researchers. In this study, wheeze ever is defined as any history of wheezy breathing; current wheezing is a history of at least 1 attack of wheezing during the last 12 months; diagnosed asthma is the same as wheeze ever plus a doctor's diagnosis of asthma.

Allergic rhinitis was diagnosed by enquiring with questions such as history of sneezing or blocked nose during the last 12 months when he/she did not have a cold or flu and has your child ever had hay fever? Questions concerning the diagnosis of eczema were as follows: has your child ever had a recurrent itchy rash for at least 6 months and has your child ever had eczema.

The height and weight of all the children were measured. BMI was calculated by dividing weight in $\mathrm{kg}$ by the square of the height in meters $\left(\mathrm{kg} / \mathrm{m}^{2}\right)$ [20]. The BMI was found to be the single best predictor of body fatness in children [21]. The BMI values of the patients in the study were compared with the international cutoff points per age and sex provided by Cole et al [22]. Overweight was defined as BMI of the age- and sexspecific $>85^{\text {th }}$ to $<95^{\text {th }}$ percentile, and obesity as BMI greater than the $95^{\text {th }}$ percentile [23]. The sample size was 750 , and was calculated using the following formula:

$$
n=\frac{z^{2} \times p(1-p)}{d^{2}}
$$

In our study, $\mathrm{d}=0.012, \mathrm{z}=1.96$, and $\mathrm{p}=0.028$ (according to the prevalence of asthma symptoms and obesity among school children in other studies) [24]. The results were analyzed statistically by applying the Student's t-test and the chi-square test; $\mathrm{p}<0.05$ was considered significant.

\section{Results}

Parents of 903 children responded to the questionnaire (response rate, 90.3\%). Approximately 34\% of the children were male and $66 \%$ were female. The median age was 8.95 years. The lifetime prevalence of wheezing (wheeze ever) was $21.56 \%$. The current prevalence of wheezing was $8.7 \%$ and of doctor-diagnosed asthma was 2\% (Table 1).

In this study, prevalence of current wheezing during the past 12 months decreased with increasing age ( $\mathrm{p}<$ 0.02 ) (Table 2), and current prevalence of wheezing was higher among boys than girls (12\% vs. $7 \%$, respectively; $\mathrm{p}=0.012$ ) (Table 3 ). The prevalence of obesity and overweight among the children was $6.87 \%$ and $9.5 \%$, respectively. The prevalence of obesity and overweight among girls and boys was found to be different (Table 4).

The current prevalence of wheezing among obese children was $68.75 \%$ and among overweight children was $37 \%$, and there was a statistical association between

Table 1 Prevalence of asthma symptoms among schoolage children

\begin{tabular}{lcc}
\hline Symptoms & No. & $\%$ \\
\hline Wheeze ever & 194 & 21.56 \\
Wheeze in the past year & 79 & 8.7 \\
Doctor-diagnosed asthma ever & 17 & 2 \\
Night cough & 65 & 7.2 \\
Exercise-induced wheeze & 31 & 3.4 \\
\hline
\end{tabular}

Table 2 Prevalence of wheeze in the past year in different ages

\begin{tabular}{cccc}
\hline Age (yrs) & No. & \multicolumn{2}{c}{ Wheeze in the Past Year } \\
\cline { 3 - 4 } & & No. & $\%$ \\
\hline 7 & 193 & 25 & 13 \\
8 & 180 & 20 & 11.1 \\
9 & 183 & 15 & 8.2 \\
10 & 172 & 11 & 6.4 \\
11 & 175 & 8 & 4.6 \\
\hline
\end{tabular}

Table 3 Prevalence of wheeze in the past year with significant difference in the both sexes

\begin{tabular}{cccc}
\hline Wheeze in the Past Year & Boy & Girl & Total \\
\cline { 2 - 4 } & $\mathbf{N}=\mathbf{3 0 8}$ & $\mathbf{N}=\mathbf{5 9 5}$ & $\mathbf{N}=\mathbf{9 0 3}$ \\
\hline \multirow{3}{*}{ 12-month prevalence of wheezing } & No. (\%) & No. (\%) & No. (\%) \\
\cline { 2 - 4 } & $37(12)$ & $42(7)$ & $79(8.7)$ \\
\hline
\end{tabular}


Table 4 Prevalence of obesity and overweight in schoolage children by sex

\begin{tabular}{ccccc}
\hline \multirow{2}{*}{ Sex } & \multicolumn{2}{c}{ Prevalence } & \multicolumn{2}{c}{$\%$} \\
\cline { 2 - 5 } & \multicolumn{2}{c}{ Overweight } & \multicolumn{2}{c}{ Obesity } \\
\cline { 2 - 5 } & No. & $\%$ & No. & $\%$ \\
\hline Both & 86 & 9.5 & 62 & 6.87 \\
Boys & 34 & 11 & 29 & 9.4 \\
Girls & 52 & 8.73 & 33 & 5.54 \\
\hline
\end{tabular}

prevalence of current wheezing and obesity $(\mathrm{p}<0.001)$. Current wheezing during the past 12 months increased with increasing weight (Table 5).

There was no statistical association between obese and overweight children with current wheeze in either sex ( $\mathrm{p}=0.18)$.

The frequencies of night cough among obese and overweight children with current wheezing was 37 (46.84\%) and 26 (32.91\%) respectively, but among normal-weight children with current wheezing it was 2 $(2.53 \%)(\mathrm{p}<0.001, \mathrm{P}<0.001$, respectively) followed by $14(17.72 \%)$ cases without night cough (Figure 1). The prevalence of night cough was higher in obese and overweight children than in normal-weight children $(\mathrm{p}<$ 0.001).

Our analysis showed that $23.4 \%$ of obese children and $15.5 \%$ of overweight children had current symptoms of exercise-induced wheeze, but only $0.4 \%$ of non-obese children had current symptoms of exercise-induced wheeze $(\mathrm{p}=0.009)$ (Table 5).

Our study demonstrated that $4.6 \%$ of obese children and $5 \%$ of overweight and normal-weight children had a history of allergic rhinoconjunctivitis, and the prevalence of eczema among obese, overweight, and normal-weight children was $1.5 \%, 2.3 \%$, and $2.6 \%$, respectively. There was no significant statistical association between obese, overweight, and normal-weight children in eczema and allergic rhinoconjunctivitis ( $\mathrm{p}>0.05$ ).

\section{Discussion}

This study showed that obese children had significantly higher prevalence of current wheezing than children of normal weight $(68.7 \%$ vs. $0.53 \%)$. Also, the prevalence of current wheezing among overweight children was higher than in normal-weight children (37\% vs. $0.53 \%)$. These associations are consistent with other studies [11,25-32].

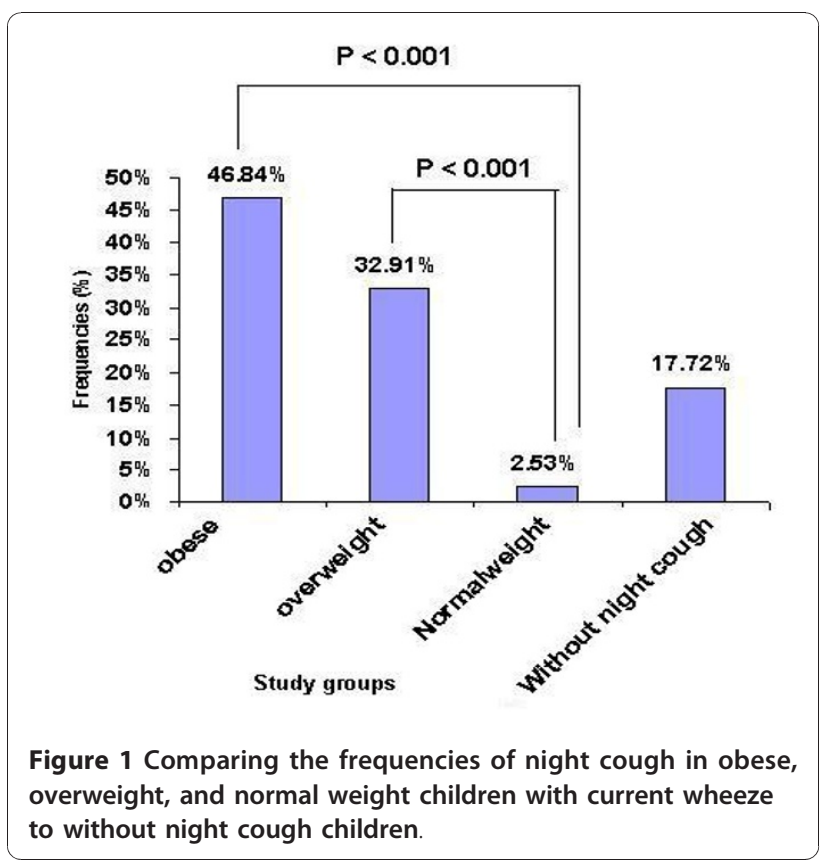

Our findings demonstrated an increased prevalence of exercise-induced wheezing among overweight and obese children compared with that in normal-weight children. Obese children had 58 times the prevalence of exerciseinduced wheezing than normal-weight children $(23.4 \%$ vs. $0.4 \%$ ), and there was 38 times the prevalence of exercise-induced wheezing among overweight children in comparison with normal-weight children $(15.5 \%$ vs. $0.4 \%)$. Our findings are consistent with other studies $[33,34]$.

Exertional wheeze in overweight and obese subjects may be due to an increase in the work of breathing, with upper airway collapse or changes in lung mechanics increasing the load on the upper airways. Other proposed mechanisms of exercise-induced wheezing include: 1) mucosal drying and increased osmolality stimulating mast cell degranulation, and 2) rapid airway rewarming after exercise causing vascular congestion, increased permeability, and edema leading to obstruction [35].

In our study, the relationship between current wheezing and obesity and overweight was independent of sex $(\mathrm{p}=0.18)$. This finding was consistent with reports by others $[26,30,36-38]$, but some reports have noted the

Table 5 Prevalence of current wheezing and exercise-induced wheezing among obese, overweight and normal weight school-age children

\begin{tabular}{|c|c|c|c|c|c|c|c|}
\hline \multirow[t]{2}{*}{ Symptoms } & \multicolumn{2}{|c|}{ Obesity N = 64} & \multicolumn{2}{|c|}{ Overweight $\mathrm{N}=84$} & \multicolumn{2}{|c|}{ Normal weight $\mathrm{N}=755$} & \multirow[t]{2}{*}{$p$ value } \\
\hline & No. & $\%$ & No. & $\%$ & No & $\%$ & \\
\hline Wheeze in the past year & 44 & 68.75 & 31 & 37 & 4 & 0.53 & $<0.001$ \\
\hline
\end{tabular}


association only in women, or that it was stronger in women $[8,11,39,40]$. This inconsistency in results for boys and girls between studies may be attributed to differences in study populations, the age distribution of participants, and different definitions of asthma used.

Despite a strong association of obesity with current wheezing and exercise-induced wheezing, no association was found between obesity and allergic rhinoconjunctivitis and eczema. This contradicts results from some studies [41,42], but is consistent with results from some other studies $[27,43]$.

If one assumes that subjects without a history of allergy are less likely to have allergic asthma, our observations suggest that excessive symptoms of current wheezing and exercise-induced wheezing among overweight and obese children may be due to causes other than allergy. Obesity and overweight are associated with an increase in the occurrence of both gastro-esophageal reflux and sleep apnea [44], and both of these conditions may mimic the symptoms of wheeze or cough without changes in lung function or airway responsiveness [45].

On the basis of these findings, overweight and obesity seem to be significant risk factors for current wheezing and exercise-induced wheezing; if these can be considered to be modifiable risk factors, interventions that affect weight loss could be associated with a decrease in asthma symptoms. Thus, children with co-morbid asthma and obesity should be encouraged to increase physical activity and lose weight.

There are several limitations in this study because it is a cross-sectional study; the data did not provide direct information on whether obesity preceded the development of asthma, which has been discussed in previous studies $[10,11]$. A measurement of airway responsiveness is desirable but not practical in studies like ours, and we did not have objective measures for the allergic status.

In conclusion, the results of this study suggest that in our region there is a strong association between asthma symptoms and both overweight and obesity in both sexes among school-age children.

\section{Acknowledgements}

This study was supported by the research deputy of Jundishapur University of Medical Sciences. The authors would like to thank Mr. Charaghian for his help in statistical analysis of the results and Research Consulting center (RCC) for their participation in manuscript revision.

\section{Author details \\ 'Pediatric Department, Abuzar Children's Hospital, Ahvaz Jondishapour University of Medical Sciences, (Golestan street), Ahvaz, Iran. ${ }^{2}$ Pediatric Department, Golestan Children's Hospital, Ahvaz Jondishapour University of Medical Sciences, (Golestan street), Ahvaz, Iran. ${ }^{3}$ Pediatric Cardiology Department, Iran University of Medical Sciences,(valiasr street)Tehran, Iran.}

\section{Authors' contributions}

All authors contributed to all aspects, including searching the literature and writing the article. All authors have read and approved the final manuscript.

\section{Competing interests}

The authors declare that they have no competing interests.

Received: 17 June 2010 Accepted: 6 January 2011

Published: 6 January 2011

\section{References}

1. Redd SC: Asthma in the United States burden and current theories. Environ Health Perspect 2002, 110(4):557-60.

2. Asher MI, Barry D, Clayton T, Crane J, D'Souza W, Ellwood P, Ford RP, Mackay R, Mitchell EA, Moyes C, Pattemore P, Pearce N, Stewart AW: International Study of Asthma and Allergies in Childhood (ISAAC) Phase One. The burden of symptoms of asthma, allergic rhinoconjunctivitis and atopic eczema in children and adolescents in six New Zealand centres: ISAAC Phase One. N Z Med J 2001, 114(1128):114-20.

3. ISAAC Steering Committee: Worldwide variation in prevalence of symptoms of asthma, allergic rhinoconjunctivitis, and atopic eczema: ISAAC. The International Study of Asthma and Allergies in Childhood (ISAAC) Steering Committee. Lancet 1998, 351:1225-32.

4. Mannino DM, Homa DM, Redd SC: Involuntary smoking and asthma severity in children: data from the third National Health and Nutrition Examination survey. Chest 2002, 122:409-15.

5. Pekkanen J, Xu B, Jarvelin MR: Gestational age and occurrence of atopy at age 31: a prospective birth cohort study in Finland. Clin Exp Allergy 2001, 31:95-102.

6. Woolcock AJ, Peat JK: Evidence for the increase in asthma worldwide. Ciba Found Symp 1997, 206:122-34.

7. Mokdad AH, Serdula MK, Dietz WH, Bowman BA, Marks JS, Koplan JP: The spread of the obesity epidemic in the United States, 1991-1998. JAMA 1999, 282(16):1519-22.

8. Figueroa-Munoz J, Chinn S, Rona R: Association between obesity and asthma in 4-11 year old children in the UK. Thorax 2001, 56:133-7.

9. Moudgil $\mathrm{H}$ : Prevalence of obesity in asthmatic adults. BMJ 2000, 321(7258):448.

10. Camargo CA Jr, Weiss ST, Zhang S, Willett WC, Speizer FE: Prospective study of body mass index, weight change, and risk of adult-onset asthma in women. Arch Intern Med 1999, 159(21):2582-8.

11. Castro-Rodríguez JA, Holberg CJ, Morgan WJ, Wright AL, Martinez FD: Increased incidence of asthmalike symptoms in girls who become overweight or obese during the school years. Am J Respir Crit Care Med 2001, 163(6):1344-9.

12. Hakala K, Stenius-Aarniala B, Sovijarvi A: Effects of weight loss on peak flow variability, airways obstruction, and lung volumes in obese patients with asthma. Chest 2000, 118:1315-21.

13. Stenius-Aarniala B, Poussa T, Kvarnström J, Grönlund EL, Ylikahri M, Mustajoki P: Immediate and long term effects of weight reduction in obese people with asthma: randomised controlled study. BMJ 2000, 320(7238):827-32.

14. Redd SC, Mokdad AH: Invited commentary: obesity and asthma: new perspectives, research needs, and implications for control programs. Am J Epidemiol 2002, 155:198-202.

15. Shaheen SO, Sterne JA, Montgomery SM, Azima H: Birth weight, body mass index and asthma in young adults. Thorax 1999, 54:396-402.

16. Wickens K, Barry D, Friezema A, Rhodius R, Bone N, Purdie G, Crane J: Obesity and asthma in 11-12 year old New Zealand children in 1989 and 2000. Thorax 2005, 60(1):7-12.

17. Beuther DA, Sutherland ER: Overweight, obesity, and incident asthma: a meta-analysis of prospective epidemiologic studies. Am J Respir Crit Care Med 2007, 175(7):661-6, Epub 2007 Jan 18. [PMID: 17234901].

18. Asher MI, Keil U, Anderson HR, Beasley R, Crane J, Martinez F, Mitchell EA, Pearce N, Sibbald B, Stewart AW, Strachan D, Weiland SK, Williams HC: International Study of Asthma and Allergies in Childhood (ISAAC): rationale and methods. Eur Respir J 1995, , 3: 483-91.

19. Weiland SK, Beasley R, Strachan D: Guidelines for the translation of questionnaires. Münster Germany: ISAAC phase one coordinating committee; 1993.

20. Daniels SR, Khoury PR, Morrison JA: The utility of body mass index as a measure of body fatness in children and adolescents: differences by race and gender. Pediatrics 1997, 99:804-7.

21. Roche AF, Siervogel RM, Chumlea C, Webb P: Grading body fatness from limited anthropometric data. Am J Clin Nutr 1981, 34:2831-8. 
22. Cole TJ, Bellizzi MC, Flegal KM, Dietz WH: Establishing a standard definition for child overweight and obesity worldwide: international survey. BMJ 2000, 320(7244):1240.

23. Aggarwal T, Bhatia RC, Singh D, Sobti PC: Prevalence of obesity and overweight in affluent adolescents from Ludhiana, Punjab. Indian Pediatr 2008, 45:500-2.

24. Mirsaeid Ghazi B, Sharifi SH, Goodarzipoor K, Aghamohammadi A, Atarod L, Rezaei N, Kouhi A: The Prevalence of Asthma among the Students (7-18 Years Old) in Tehran during 2002-2003. Iran J Allergy Asthma Immunol 2004, 3(2):89-92

25. Gilliland FD, Berhane K, Islam T, McConnell R, Gauderman WJ, Gilliland SS, Avol E, Peters JM: Obesity and the risk of newly diagnosed asthma in school-age children. Am J Epidemiol 2003, 158(5):406-15.

26. Beuther DA, Sutherland ER: Overweight, obesity, and incident asthma: a meta-analysis of prospective epidemiologic studies. Am J Respir Crit Care Med 2007, 175:661-6.

27. Schachter LM, Salome CM, Peat JK, Woolcock AJ: Obesity is a risk for asthma and wheeze but not airway hyperresponsiveness. Thorax 2001, 56(1):4-8.

28. Luder E, Melnik TA, Dimaio M: Association of being overweight with greater asthma symptoms in inner city black and Hispanic children. Pediatrics 1998, 132:699-703.

29. Romieu I, Avenel V, Leynaert B, Kauffmann F, Clavel-Chapelon F: Body mass index, change in body silhouette, and risk of asthma in the $\mathrm{E} 3 \mathrm{~N}$ cohort study. Am J Epidemiol 2003, 158(2):165-74.

30. Nystad W, Meyer HE, Nafstad P, Tverdal A, Engeland A: Body mass index in relation to adult asthma among 135,000 Norwegian men and women. Am J Epidemiol 2004, 160(10):969-76.

31. Young SN, Gunzenhauser JD, Malone KE, Tiernan AM: Body mass index and asthma in the military population of the northwestern United States. Arch Intern Med 2001, 161:1605-11.

32. Cassol VE, Rizzato TM, Teche SP, Basso DF, Centenaro DF, Maldonado M, Moraes EZ, Hirakata VN, Solé D, Menna-Barreto SS: Obesity and its relationship with asthma prevalence and severity in adolescents from southern Brazil. J Asthma 2006, 43(1):57-60.

33. Kaplan TA, Montana E: Exercise-induced bronchospasm in non-asthmatic obese children. Clin Pediatr 1993, 32:220-5.

34. Del Río-Navarro B, Cisneros-Rivero M, Berber-Eslava A, Espínola-Reyna G, Sienra-Monge J: Exercise induced bronchospasm in asthmatic and nonasthmatic obese children. Allergol Immunopathol (Madr) 2000, 28(1):5-11, PubMed PMID: 10757851.

35. Tan RA, Spector SL: Exercise-induced asthma. Sports Med 1998, 25:1-6.

36. Jarvis D, Chinn S, Potts J, Burney P: Association of body mass index with respiratory symptoms and atopy: results from the European Community Respiratory Health Survey. Clin and Exp Allergy 2002, 32:831-7.

37. Ford ES, Mannino DM, Redd SC, Mokdad AH, Mott JA: Body mass index and asthma incidence among USA adults. Eur Respir J 2004, 24(5):740-4.

38. Beuther DA, Sutherland ER: A meta-analysis of prospective epidemiologic studies. Am J Resp and Crit Care Med 2007, 175:661-6.

39. Chen Y, Dales R, Krewski D, Breithaupt K: Increased effects of smoking and obesity on asthma among female Canadians. The National Population Health Survey 1994-1995. Am J Epidemiol 1995, 15:255-62.

40. Chen $Y$, Dales $R$, Tang M, Krewski D: Obesity may increase the incidence of asthma in women but not in men: longitudinal observation from the Canadian National Population Health Surveys. Am J Epidemiol 2002, 155:191-7.

41. Huang SL, Shiao G, Chou P: Association between body mass index and allergy in teenage girls in Taiwan. Clin Exp Allergy 1999, 29:323-9.

42. Chinn S, Jarvis D, Burney P: European Community Respiratory Health Survey.Relation of bronchial responsiveness to body mass index in the ECRHS. European Community Respiratory Health Survey. Thorax 2002, 57(12):1028-33.

43. Chen $Y$, Dales $R$, Jiany $Y$ : The association between obesity and asthma is stronger in nonallergic than allergic adults. Chest 2006, 130:890-5.

44. Grunstein RR, Wilcox I: Sleep-disordered breathing and obesity. Baillieres Clin Endocrinol Metab 1994, 8:601-28.

45. Gunnbjörnsdóttir MI, Omenaas E, Gíslason T, Norrman E, Olin AC, Jõgi R, Jensen EJ, Lindberg E, Björnsson E, Franklin K, Janson C, Gulsvik A, Laerum B, Svanes C, Torén K, Tunsäter A, Lillienberg L, Gíslason D, Blöndal T, Björnsdottir US, Jörundsdóttir KB, Talvik R, Forsberg B, Franklin K, Lundbäck B, Söderberg M, Ledin MC, Boman G, Norbäck D, Wieslander G,
Spetz-Nyström U, Cashelunge KS, Rydén E: RHINE Study Group. Obesity and nocturnal gastro-oesophageal reflux are related to onset of asthma and respiratory symptoms. Eur Respir J 2004, 24(1):116-21.

doi:10.1186/1824-7288-37-1

Cite this article as: Kajbaf et al:: Relationship between obesity and asthma symptoms among children in Ahvaz, Iran: a cross sectional study. Italian Journal of Pediatrics 2011 37:1.

\section{Submit your next manuscript to BioMed Central and take full advantage of:}

- Convenient online submission

- Thorough peer review

- No space constraints or color figure charges

- Immediate publication on acceptance

- Inclusion in PubMed, CAS, Scopus and Google Scholar

- Research which is freely available for redistribution

Submit your manuscript at www.biomedcentral.com/submit
C Biomed Central 